\title{
An Analysis of the Influence of Electable(s) on Democracy in Pakistan (1988-2019)
}

\author{
Usman Khan \\ Ph.D Scholar \\ Qurtaba University of Science and Information Technology \\ Peshawar Khyber Pakhtunkhwa - Pakistan, \\ usman.pol@uom.edu.pk \\ $\&$ \\ Dr. Aziz ur Rahman \\ Assistant Professor \\ Department of Political Science \\ Qurtaba University of Science and Information Technology \\ Peshawar Khyber Pakhtunkhwa - Pakistan
}

$\&$

Dr. Muhammad Kashif

Superintendent, D. R. (E).,

University of Karachi,

Karachi - PakistanEmail:

m03002616437@yahoo.com

\begin{abstract}
This paper explores the impacts and influence of electable(s) on parliamentary democracy in Pakistan during the last three decades (1988-2019). The paper argues that Alavi's state power structure, dominated by civil-military bureaucracy, has undergone a change in the last few decades. New forces like intermediate class, a segment of superior courts' judges and some of the politicians known as electable(s) have been able to occupy space in the Pakistani state power structure. This paper argues that electable(s) remain connected with the powerful establishment only for the purpose to obtain their personal interests at the cost of weakening parliamentary democracy in Pakistan. Data is collected through personal communications with a diverse group of people having expertise in their respective fields.
\end{abstract}




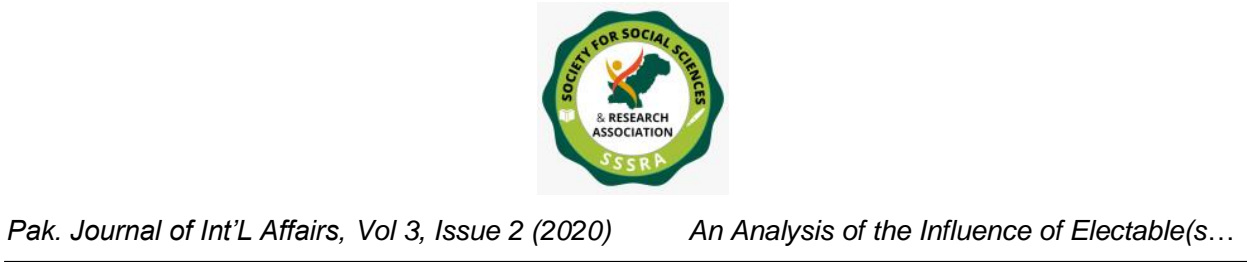

Keywords: state power structure, civil-military oligarchy, intermediate class, electable(s), parliamentary democracy

\section{Introduction}

Akhtar and Zaidi in their studies demonstrate that Alavi's state power structure in Pakistan has undergone a change in the last few decades (McCartney \& Zaidi, 2019). According to Hamza Alavi, post-colonial Pakistani state power structure has been dominated by the civil-military bureaucracy, and indigenous and metropolitan bourgeoisies (Alavi, 1972). However, Akhtar opines that a new class, i.e. intermediate class has emerged which has found position in the state power structure of Pakistan (Akhtar, 2018). On the other hand, Zaidi argues that media and higher judiciary in the last two decades have also been entered into the Pakistani state power structure (Zaidi, 2014). In addition to Alavi's (1972), Akhtar's (2018) and Zaidi's (2014) findings, this paper argues that electable(s) has also been able to find space in Pakistani power structure.

\section{Electable(s)}

The political history of Pakistan of the last three decades (1988-2018) reveals that some politicians in Pakistan have frequently changed their party loyalties. They always try to remain connected with the establishment dominated by civil and military bureaucracy. In this connection Professor Ahmad Yousaf told me in telephonic conversation that there are politicians who always remain connected to the establishment in order to pursue their political and economic interests. The respondent was of the view that such politicians, generally move from party to party based on every election cycle, seek their vested interests at the cost of weakening parliamentary democracy in Pakistan (Yousaf, personal communication, $13^{\text {th }}$ May, 2020). Another respondent, Saeed Malik hailing from a political family in Khyber Pakhtunkhwa commented,

"Politics of the last three decades (1988-2019) best depicts politicians who frequently changed their party loyalties. The respondent added, 'our elders have changed nearly four political parties in short span of 20 years'. He stated that electable(s) are coupled together to complete the required majority of the government" (Malik, personal communication, $8^{\text {th }}$ August, 2020). 


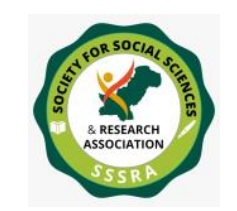

An Analysis of the Influence of Electable(s...

Further, the same respondent shared a list of politicians who had been ministerial portfolios under different military and democratic regimes. Among them, Shah Mehmood Qureshi, Pervaiz Khattak, Khusro Bakhtiar, Umar Ayub, Zubaida Jalal, Fahmida Mirza, Sheikh Rasheed Ahamd, Shafqat Mehmood, and Fakhr Imam are ministers in the current PTI cabinet who have been the prominent figures of the previous regimes of PPP, PMLN and PLMQ (Malik, personal communication, $8^{\text {th }}$ August, 2020).

Moreover, Sayyed Sami Ullah Jan was of the opinion that some of the political parties strike compromises with the establishment in order to gain political power. The political parties lack discipline and some of them do not have ideological bases or ideological programmes to keep members within the party. Therefore, people easily leave and join parties depending on every election cycle (Jan, personal communication, $21^{\text {st }}$ July, 2020).

Thus, a segment of politicians always tries to keep in touch with power structure dominated by the powerful actors such as military and civil bureaucracy, to pursue their political and economic gains. This also led to frequent changes from one party to another that weaken party system in Pakistan which in turn affect growth of democratic culture in Pakistan. Electable(s), unlike the advanced democracies like UK where party defection is considered as a political death, bring far reaching implications on the growth of parliamentary democracy in Pakistan. The period from 1988-2019 best illustrates such politicians and their influence on the parliamentary politics of Pakistan.

\section{Alliances with the Establishment}

The politicians align themselves with establishment through co-option. Co-option is a tool which connects a segment of politicians with the authoritarian regimes for the purpose of obtaining legitimacy. Wali expressed his opinions that there are two ways that paved the way to co-option of politicians in Pakistan. One, politicians often compete with one-another and in order to defeat opponents they approach the establishment. This shows that they provide chance to military to include them in their project of making or unmaking a government. Second, the military co-opt people or parties on the basis of identity, ideology, and interests. It is fact that there are power hungry politicians in Pakistan who always try to connect with the power structure. In order to reach power corridors, they develop links with the military (Wali, personal communication, 2020). Further, the structure of power in Pakistan 


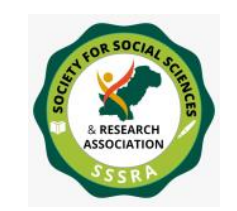

Pak. Journal of Int'L Affairs, Vol 3, Issue 2 (2020)

An Analysis of the Influence of Electable(s...

is basically driven by patronage. Christina Lamb in her book Waiting for Allah (1991) describes such practice as super-patronage where influential politicians, army and bureaucrats provide easy access to their clients to access state resources.

Sarwar Iqbal, a civil servant based in Nowshera, having practical experience of dealing with politicians informed me,

"Co-option, coordination, collaboration or conflict is largely about patronage that involves exchange of resources asymmetrical of course depending on how much power one exercise. At top exercise more and the lower level exercise the less but the structuring element is patronage essentially who one knows, how one knows those networks of contacts and that is how basically the system works where power flows from top to bottom and from bottom to top also. That is how the predominant logic of politics is to look for someone one knows who can help him navigate every day concerns and considerations" (Iqbal, personal communication, 2020).

The political history of Pakistan depicts those politicians who have been connected with the military. Aasim Sajjad Akhtar in 'The Politics of Common Sense (2018)' argues that there are even some nationalist politicians who seek power and therefore develop links with the military establishment. The author argues that veteran politicians of Pakthunkhwa Milli Awami Party (PKMAP) use nationalist rhetoric during election campaign in order to get elect themselves and when they reach corridor of powers, they shun their rhetoric and join establishment. In some ways religious parties also contain electable(s) having connections with the establishment (Akhtar, 2018). In this context Akhtar writes;

"We cannot afford to be out of government for too long - people want jobs and other things that we can only provide if in power and coming into power in Pakistan means doing a deal with the establishment. Of course we will continue to propagate anti-establishment slogans in public, but just chanting slogans does not help us meet people's everyday needs" (Akhtar, 2018, P, 127).

Moreover, there is a long list of politicians who frequently change their loyalties. Saeed Malik, hailing from a political family in Khyber Pakhtunkhwa (KP), stated that Pakistan Muslim League-Quaid (PML-Q) is the best example which was once known as the king party. This party was formed by General Musharraf before 2002 


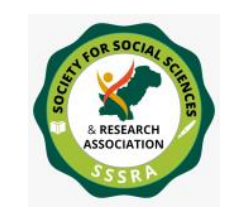

Pak. Journal of Int'L Affairs, Vol 3, Issue 2 (2020)

An Analysis of the Influence of Electable(s...

general elections and was joined by several politicians from other political parties. Similarly, MQM had the support of Zia which was formed to weaken PPP support base in the province of Sindh. The party worked for military during 1990s especially in the famous operation Mid-Night Jackal when huge sum of money was distributed among the foes and friends of Benzair Bhutto for the purpose to derail her first elected government (Malik, 2020). Malik commented that his elders have also changed party loyalties several time for the purpose to reach power corridors.

Likewise, alliance politics is also an example where politicians join hands on the behest of military. For instance, Islamic Democratic Alliance or Islami Jamhori Ittehad (IJI) during 1990s and United Council of Action (MMA) during Musharaf regime were the alliances that weakened parliamentary governance in Pakistan (Malik, personal communication, 2020). Lamb argues that IDI or IJI was the alliance of nine political parties of which the major components were Pakistan Muslim League (PML), National People Party (NPP), and Jammat-e-Islami (JI) aiming to defeat Pakistan People's Party (PPP). The alliance was backed by the Inter Service Intelligence under General Hamid Gul (Lamb, 1991, 86).

Further, MMA was an alliance of six religious political parties comprising of JI, JUI (F), JUI (S) which managed to form government in two provinces, i.e. former NWFP, and Baluchistan. Though MMA was formed against Musharraf's policy of joining the US against war on terror, yet the alliance formed a coalition government in Baluchistan with PMLQ which later on also consented to the approval of $17^{\text {th }}$ amendment that reinforced presidential system at the cost of parliamentary model of governance (Haqqani, 2010).

Again, there are ministers in the current set-up who were the partners in previous elected governments of PMLN in 2013, PPP in 2008 and PMLQ in 2002, military regime of Pervaiz Musharraf. For instance, Omar Ayub Khan, grandson of Ayub Khan, was a member of the parliament under PML (Q) in 2002, he became an MNA from the platform of PML (N) in 2013, and he joined PTI in 2018. Similarly, Ghulam Sarwar Khan was a member of parliament of PPP in 1988, he changed his party and joined PML (Q) in 2008, and currently he is a minister under the banner of PTI. There are plenty of such politicians who often used to change party loyalties for the purpose to engage within the power (Malik, personal communication, 2020). 


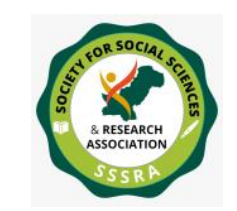

An Analysis of the Influence of Electable(s...

Current government contain politicians who are fundamentally from different parties and once belonged to the mainstream parties like PML (N), PPP, ANP, MQM, and PMLQ. Most of the respondents opined that such politicians get support from the establishment dominated by the military in Pakistan. Hence, a segment of politicians seeking power and interests weakens parliamentary system of governance in Pakistan.

\section{Electability and its Impacts on Parliamentary Form of Governance in Pakistan}

Parliamentary or Westminster ${ }^{1}$ model is a system in which people do not directly elect their government but leave it to the elected representatives to install, supervise, and remove the government (Mainwaring, 1993). Further, this system is also known as responsible or cabinet form of government because the executive or cabinet is taken of and responsible to the legislature, i.e. parliament ( Sargentich,. 1992). Parliamentary democracy is based on certain fundamental principles like supremacy of the parliament, an accountable cabinet, disciplined political parties, fair and transparent elections, rule of law and civil liberties (Dicey, 2005).

The system is successful in societies such as England where it took centuries to evolve (Ogg, 1936). In England, the parliament is supreme to the extent that it cannot be questioned even in the court of law (Dicey, 2005). Further, the executive or cabinet is coherent and coordinated and collectively responsible to the popularly elected body. In England, if a minster is failed to justify his function or a bill in the parliament, the whole cabinet has to leave the office (Mazhar Ul-Haq, 1999, pp. 325-337).) Similarly, in England, political parties are disciplined and if a person changes his party, it is considered as a political death (Szilagyi, 2009). Moreover, elections, which are the foremost requirements of a successful representative democracy, are fair and transparent in England. Last, rule of law is the guiding principle of the whole English parliamentary system where everyone is equal to law, treated under the same law, and none is above the law (Ogg, 1936)

Unlike developed parliamentary democracies such as England, Parliament and its sovereignty often remain weak in Pakistan due to the presence of those politicians who always seek power and personal interests rather than public interests. Such

\footnotetext{
${ }^{1}$ This term comes from the Palace of Westminster, the seat of the British Parliament. For detail see, A.V dicey's (2005), law of the nature of constitution, Sange Meel Publication, Lahore.-
} 


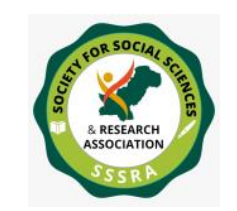

Pak. Journal of Int'L Affairs, Vol 3, Issue 2 (2020)

An Analysis of the Influence of Electable(s...

politicians weaken parliamentary democracy by various ways. One, they could not be trusted because they jump from one party to another which weakens mass support required for a sovereign parliament. Sareer Wali, professor in Public Sector University shared an interesting anecdote,

"In 2013, one of my friends persuaded me to vote for PTI. I voted to PTI and my friend voted to PMLN on the basis that his relative was affiliated with PMLN. The respondent added, in the next election, my friend again tried to persuade me to vote PMLN. I voted PMLN while my friend to PTI. I asked my friend about it. He told that his relative has shifted the party from PMLN to PTI. Therefore, I gave vote to PTI. This is how patronage works in Pakistan" (Wali, personal communication, 2020).

Two, the required majority to form a government could not be acquired because of disloyal politicians. In this regard, Bilal Ahmad commented in personal communication that throughout 1988-2019, neither of the elected governments in Pakistan, except in 1997, has acquired the requisite majority of seats to form a uniform government. Of course, this happens due to multiplicities of political parties in Pakistan. He added that politicians changing parties naturally weaken party system. Consequently, a uniform or single party government could not be formed in Pakistan. Diverse groups inside the parliament representing diverse interests lead to a fragile and weak parliament (Ahmad, 2020).

Because of electable(s), the elected governments during 1988-2019 remained weak. Another respondent Gul Marjan, a professor and journalist, commented that first government of Benazir Bhutto lacked support from within the parliament. Similarly, government of Nawaz Sharif in 1990 was far behind than required majority. Again, Benazir Bhutto lacked seats to from a single party government in 1993. During 1988-1996, every government was too weak to legislate and execute because of some of the dishonest politicians (Marjan, 2020).

The same interviewee stated that PML (N) had managed an overwhelming majority in 1997. The government was stable and therefore passed certain amendments and legislations like $13^{\text {th }}$ amendment which relatively strengthened parliamentary democracy in Pakistan. However, Nawaz Sharif was unable to exploit his strength. His collisions with judiciary, in the famous Sajjad Ali Shah case, and with military weakened him that caused his decline in 1999. Though Nawaz had mass support in the form of a heavy mandate but he could not utilize it 


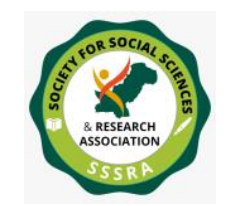

Pak. Journal of Int'L Affairs, Vol 3, Issue 2 (2020)

An Analysis of the Influence of Electable(s...

properly (Marjan, 2020). Likewise, in 2008 PPP had to rely on coalition partners. Again, in 2013, Nawaz could not manage to win a clear majority. In both these cases, prime ministers were sent home by the judiciary. It would not have been possible if PPP and PMLN had a clear majority and support within the parliaments.

Three, electable(s) having connections with establishment weaken other political parties and politicians. Javaid contends that MQM was formed to weaken PPP base in Sindh. Similarly, Tehreek e Labbaik of a religious far-right cleric, Khadim Hussain Rizvi, was formed to weaken PMLN support base in Punjab (Javed, 2018).

Four, the presence of electable(s) weakens coalition government. Aasim Sajjad Akhtar in an interview with Institution of South Asian Studies at the National University Singapore commented that government of Imran Khan is weak because it is a coalition of diverse parliamentarians. Such parliamentarians join government on certain conditions like awarding them important portfolios, ministries and some funds. It is a fact that Pakistani politics is characterised by patronage. Coalition partners need funds to keep their voters happy. A weak and fragile coalition does not regret its partners' demands. Moreover, a coalition government could not take actions against its partners as has happened in recent sugar, wheat and oil crisis where close aides of Imran Khan were involved (Akhtar, 2020).

In this context, Salar commented in telephonic interview that coalition government has to keep its partners happy and despite doing wrong the government could not take actions against them. A formula commonly known in Pakistan, minus-one formula, could possibly be applied. This formula implies that in order to put pressure and threaten elected government, a minister could be sacked, replaced or compelled to withdraw his membership from the parliament or cabinet any time (Salar, personal communication, 2020).

Moreover, such politicians being within the elected assemblies have close connections with the military establishment. Sareer Wali was of the opinion that they could not do legislation which may threaten institutional interests of the establishment dominated by civil-military bureaucracy. For instance, the government extended services of COAS Qamar Javed Bajwa last year. The apex court challenged extension of the army chief on ground of missing provision in constitution pertaining to extension. It was sent to the parliament for legislation 
where all the parliamentarians except few unanimously passed an amendment which validated the extension of army chief. The respondent added that this is how politicians in Pakistan give chance to military to intervene and run affairs of the state (Wali, personal communication, 2020).

\section{Conclusion}

The passages inform us that there are some politicians who often jump from one party to another at times of elections. Such politicians are termed as electable(s) and the phenomenon is known as electability. Further, such power hungry politicians seek interests at the expense of weakening parliamentary democracy in Pakistan. To accomplish their interests, they develop connection and alliances with the establishment which consequently strengthens authoritarianism at the expense of parliamentary democracy in Pakistan. Parliamentary democracy like in UK needs a sovereign parliament, discipline political parties, and an accountable cabinet or executive. Nevertheless, in the presence of disloyal and untrustworthy politicians parliamentary democracy in Pakistan could not be strengthened. 


\section{References}

Akhtar, A. S. (2018). The Politics of Common Sense: State, Society and Culture in Pakistan: Cambridge University Press.

Alavi, H. (1972). The State in Post-Colonial Societies Pakistan and Bangladesh. New Left Review. 74 (1) https://newleftreview.org/issues/i74/articles/hamza-alavithe-state-in-post-colonial-societies-pakistan-and-bangladesh.

Dicey, A. V. (2005). An Introduction to the Study of the Law of the Constitution London: Macmillain.

Mazhar-ul-Haq (1999). Political Science: Theory and Practice. Lahore: Bookland.

Haqqani, H. (2010). Pakistan: Between Mosque and military: Carnegie Endowment.

Javed, U. (2018). The Struggle for Control of Pakistan's Fragile Democracy. Current History, 117(798), 123-128.

Lamb, C. (1991). Waiting for Allah. Pakistan's Struggle for Democracy, New Delhi: Viking Penguin Book.

Mainwaring, S. (1993). Presidentialism, Multipartism, and Democracy: The Difficult Combination. Comparative Political Studies, 26(2), 198-228.

McCartney, M., \& Zaidi, S. A. (2019). New Perspectives on Pakistan's Political Economy: State, Class and Social Change (Vol. 9): Cambridge University Press.

Ogg, F. A. (1936). Englisg Government and Politics New York: The Machmillan Company.

Szilagyi, I. M. (2009). Presidential Versus Parliamentary Systems. AARMS, 8(2). 307-314.

Sargentich. T. O. (1992). The Presidential and Parliamentary Models of National Government. American University Journal International Law and Policy 8. 579592. 
Zaidi, S. A. (2014). Rethinking Pakistan's Political Economy: Class, State, Power, and Transition. Economic and Political Weekly, 47-54. 